\title{
Abnormal Lobation
}

National Cancer Institute

\section{Source}

National Cancer Institute. Abnormal Lobation. NCI Thesaurus. Code C124488.

The formation of a lobe of tissue that is aberrant in comparison to normal anatomy. 